\title{
Violence, communication, and satisfaction among middle-aged adults and older people from Romania
}

Cornelia Rada ${ }^{1 凶}$

Data on intimate partner violence (IPV) are necessary when planning public health policies aimed at prevention and support. Family communication and satisfaction are essential for health and well-being. Here, we report the findings of a quantitative cross-sectional study performed between 2016 and 2017 on 601 patients (55-93-years-old) who were treated at the Ana Aslan National Institute of Gerontology and Geriatrics. We explore the answers to one item on the omnibus questionnaire (man-on-women, woman-on-man) regarding: (1) insults, swearing, humiliation; (2) being forced to engage in unwanted sexual intercourse; (3) withholding sexual activity or affection; (4) slapping, kicking, pushing; (5) hitting with a stick or other objects; (6) threatening with a knife or firearm; and (7) financial control, neglect, or food deprivation. Also, the Family Communication Scale (FCS) and Family Satisfaction Scale (FSS) are used. IPV prevalence was generally high, especially for the categories of insults, swearing, humiliation, withholding sexual activity, and affection. More women than men reported IPV, especially insults, swearing, and humiliation. More than a quarter of respondents (men and women) suffered occasionally or often from a form of abuse and experienced emotional abuse. The potential of family communication and satisfaction is relatively good, and these are associated. In the case of low and very low family communication and satisfaction, IPV prevalence was higher for all categories. There is a vicious circle because, on the one hand, violence can provoke emotional distance, and, on the other hand, a lack of intimacy and communication can lead to violence. At the same time, low satisfaction in a relationship can be seen both as a cause and as an effect of violence. Programs and information materials addressing family violence are rarely aimed at people in middle adulthood or older people and are instead focused on young women and children. We believe that this imbalance should be redressed.

\footnotetext{
${ }^{1}$ Biomedical Department, Francisc I. Rainer Anthropology Institute of the Romanian Academy, Bucharest, Romania. ${ }^{凶}$ email: corneliarada@yahoo.com
} 


\section{Introduction}

- here are nine distinct forms of violence and abuse: physical violence, sexual violence, emotional violence, psychological violence, spiritual violence, cultural violence, verbal abuse, financial abuse, and neglect (Newfoundland and LabradorCanada, 2018).

"Intimate partner violence (IPV) is abuse or aggression that occurs in a close relationship. Intimate partner refers to both current and former spouses and dating partners" (National Center for Injury Prevention and Control, Division of Violence Prevention, USA, 2019). The partner, male or female, (i.e., spouse, boyfriend/girlfriend, dating partner, or ongoing sexual partner) engages in physical, sexual violence, stalking and psychological aggression. Intimate partner violence (IPV) is sometimes called domestic violence (Breiding et al., 2015).

Domestic violence against children and partners has major psychological consequences because of the paradox that the victim is abused by a family member who is expected to express support, love, and respect. The studies also indicated that violent behavior might be transmitted across generations. Rada (2014) clearly found that the highest proportions of all types of violence among couples were when they were also victims of domestic violence in childhood or adolescence.

Some studies have described intimate partner violence (IPV) within the context of patriarchal terrorism, stating that it is a result of a global model of power and control (Loseke and Kurz, 2005). Other studies have referred to IPV from a situational perspective and identified it as a result of a person's incapacity to efficiently manage conflict (Bonnet, 2015; Rees et al., 2014).

It might be assumed that only men abuse women physically. However, there are studies reporting that women were as violent as men in intimate relationships (Archer, 2000) or that men and women attending general practice experience IPV, though patterns differ (Paul et al., 2006). Another complication is that some women who have been tried for domestic violence are, in fact, beaten women who defended themselves (Swan et al., 2008).

Other studies have shown that these differences are because men are less likely to report domestic violence committed by their intimate female partners (Dutton and Nicholls, 2005; Watson and Parsons, 2005).

The metanalysis of Razera et al. (2017) identified studies showing that both men and women can be perpetrators of violence, however, levels vary depending on subtypes of violence; these authors also revealed that that are more studies indicating gender asymmetry and marital violence than those indicating gender symmetry in marital violence.

Marital satisfaction is essential for health and well-being. Using semi-structured interviews on 40 couples of an average age of 76 years, Walker et al. found that the low scores at marital satisfaction were correlated to high scores on the depression scale (Walker et al., 2013).

Couple communication is a predictor of a quality relationship, and this aspect is especially important among the older people who must cope with a natural biological decline, sometimes with severe illnesses. Kwak et al. examined the association between communication and the quality of relationship among older couples in which one partner suffers from mild to moderate dementia in a sample of 43 older partners from the Couples Life Story Project and found a correlation between higher communication with the people suffering from dementia and a positive couple relationship (Kwak et al., 2015).

Data regarding domestic violence in Romania. The prevention of domestic violence and the support of victims of domestic violence are a constant concern in Romania both at among non- governmental organizations and at the governmental level. Nongovernmental activities such as the ones below have an important role to play. Since 2004, the Sensiblu Foundation has been carrying out extensive public awareness campaigns during the 16 Days of International Activism against Gender-based Violence meant to reveal the serious consequences that domestic violence has on families. Among the messages launched by these campaigns: "When you lose control, people can lose their life!" (2006); "Being indifferent, we encourage domestic violence" (2007); "You are not in prison at home. "Leave before it is too late" (2008); "Peace at home for peace in the world" (2012); and "The bruise disappears, the trauma remains" (2015) (Fundația Sensiblu, 2015).

In 2012, on the occasion of the International Day for the Elimination of Domestic violence, AVON Cosmetics Romania launched the "1000 beds" program under the aegis of the "Respect Campaign" initiated in 2008. A collection of jewelry with suggestive names was created, including The Bracelet of Courage, The Ring, The Bracelet and The Necklace of Respect, and the money earned from their sale was used to supplement the existing beds in victim shelters (Avon împotriva violenței domestic, 2013).

In October 2018, the Network for Preventing and Combating Violence against Women organized the fourth edition of the "Together for Women's Safety" march. The participation of over 1000 people was considered a sign of solidarity with women who survived episodes of violence. At the same time, the public pressure needed to respect the rights of women and girls is maintained (Rețeaua pentru prevenirea și combaterea violenței împotriva femeilor, 2018).

Non-governmental organizations that are part of the network "Break the silence about sexual violence" provide information, psychological counseling, and legal assistance in the case of sexual assault. There is also a free national telephone line available $24 \mathrm{~h}$ per day, 7 day per week, where victims receive guidance on the services they can use.

A 2008 national-level sociological survey of 1000 people and an additional sample of 304 women (total of 854 women) reported a lifetime rate of domestic violence of $14.7 \%$ for men and $21.5 \%$ for women, which was higher in urban areas. The partner was the aggressor in most (67\%) incidents. The highest incidence was recorded in the case of psychological violence (Centrul de Sociologie Urbană si Regională CURS, 2008).

A study based on interviews with 42,000 women in 2012-1500 in each of the 28 countries of the European Union-showed that $24 \%$ of women in Romania experienced violence from their partners. Most women who admitted to being affected by physical and sexual violence were in Finland, Denmark, and Latvia. In Romania, $30 \%$ of women reported having been affected by physical or sexual violence at some point in their lives after the age of 15 years, which was close to the European average (Agenția pentru Drepturi Fundamentale a Uniunii Europene Schwarzenbergplatz Vienna-Austria, 2017).

The opinion poll conducted in 2013 on a sample of 1050 people, representative of the population of Romania 18 years and over 18 years found that over $40 \%$ of Romanians have heard of cases of domestic violence within their own social networks, which shows a significant presence of the phenomenon. The structure reported by them regarding the person who was the victim is interesting. Expressed in percentages the victims were the wife -65.9 , the child / children - 37.9, the older people -19.7 , the husband-4.4 (the rest answered "someone else" or did not answer). At the statement "women are beaten also by their fault", $30.9 \%$ of the subjects agreed. However, the study also shows a positive fact, that there was a significant disagreement with some 
stereotypes such as the idea that "the battle is broken from heaven" or that "a man who does not beat his woman does not really love her" (INSCOP Research, 2013). It is the result of social campaigns aimed at raising awareness and reducing of the domestic violence phenomenon. However, it may be to some extent a discourse effect. The depth of the phenomenon is necessary to be discussed.

Violence in Romania has been analyzed, especially regional studies (Rada and Tarcea 2010; Sandu et al., 2014; Vrăbiescu, 2018), with fewer studies conducted on representative samples at a national-level.

However, it should be noted that Romanian women are relatively less likely to talk to others about their experiences of violence compared to the women of other countries. A low level of gender equality leads to greater silence regarding violence against women. In general, in the Romanian society, particularly in families, boys learn dominance and girls learn submission. Within families-especially those from lower and middle classes -if a woman expresses her opinion, this is regarded as nagging and argumentative behavior. This is especially valid for the older generations. In a Romanian study with data collected between 2009 and 2011 from 414 men and 455 women aged 18-75, distributed relatively homogeneously by area of residence, gender, educational level and age groups, Rada found that there were no statistically significant differences in reported violence before age 35 and beyond. However, domestic violence reported by people in the younger birth cohorts was lower. A first explanation is that older women had a longer exposure period, and older men had the opportunity to commit abuses over a longer period of time. A second explanation is related to the change in the mentality of young couples (Rada, 2014).

Various governmental structures have been set up in Romania to combat domestic violence and new laws have been issued that are somewhat harmonized with those of the European Union. Some examples are provided below. Under the cooperation between the Ministry of Administration and Interior of Romania and the Ministry of Interior National Relations and Ministry of Justice of the Netherlands, a Memorandum of Understanding between Romania and the Netherlands was signed covering the period 2007-2009 as concerns training and seminars meant to prevent domestic violence in rural areas. In 2008, more than 900 police members were trained under this program (UN Women, 2008a). In 2008 in Romania, there were 40 counseling centers for domestic violence victims and 56 shelters for the victims, of which 28 were public, 15 were organized by a public and private partnership, and 13 were private (UN Women, 2008b).

In 2016, the Interministerial Committee for the Prevention and Combating of Domestic Violence was established, which has a consultative role. The Government's Decision no. 365/24.05.2018, published in the Official Journal of Romania, Part I, no. 465/ 06.06.2018, implements the National Strategy on Promoting Gender Equality and Preventing and Combating Domestic Violence for 2018-2021 in correlation with all the EU public policies in this area, as well as an operational plan (Agenția Naţională pentru Egalitatea de Şanse între Femei şi Bărbaţi, 2018a).

Law no 174/2018 regarding the amendment of Law no 217/ 2003 on preventing and combating family violence, published in the Official Journal no. 618 of 18 July 2018, is the latest law in this field (http://anes.gov.ro/wp-content/uploads/2018/07/174-mod217.pdf). The regulation is a victim-centered approach that monitors protection orders/measures to prevent their violation, and provides for emergency intervention measures in situations of immediate risk (Agenția Națională pentru Egalitatea de Şanse între Femei şi Bărbați, Legislație națională-Violența în familie, 2018b).
These are commendable efforts, but it must be acknowledged that more time is needed for them to produce their effect. The mindset is more difficult to change. In addition to the legislation, statistics show more domestic violence, violence between partners officially reported. That is the one which gets to be tried in court, of the women who go to shelters to ask for help, of the people who go to the doctor of forensic medicine to request medical certificates, etc.

All forms of violence can affect the mental health of women, and associations have been reported between psychologic abuse (including controlling behavior) and depression (Lövestad et al., 2017), and can result even if women are the perpetrators (Vaeth et al., 2009).

Relevant data on domestic violence are necessary when designing public health policies aimed at prevention and support. There are few studies regarding domestic violence among the older people as a separate study group (Roberto et al., 2013).

On the one hand, the positive marital experience can enhance intimacy and favor better relationships between spouses, but on the other hand, a longer duration of marriage can increase the number of years of exposure to IPV risk (Adebowale, 2018).

The merits of this article are as follows. This present study might be useful in designing evidence-based prevention programs rather than general prevention programs.

There are only a few studies on violence in couples, family satisfaction, and communication in the last years of middle adulthood (English Oxford Living Dictionaries, 2018) (i.e., 55-64years-old) and at the third age ("young old" (65-74), "old" (74-84), and "oldest-old" (85+) (Bunker-Hellmich, 2015), and therefore, this study addresses a gap in the literature. It is the first study using both the Family Satisfaction Scale (FSS) and Family Communication Scale (FCS) in violence analysis within the family. The present study also has the merit of looking at "hidden" violence between partners such as by including those who have not sought help from police, doctors, psychologists, etc.

\section{Objectives}

Given the above background, the main objectives of the present study were to determine the following: the level of violence in the couple, the level of communication and satisfaction in the family, and possible association between these elements among middleaged and older adults. The principal question addressed is how does couple violence affect the quality of life or the perception of the quality of life, family satisfaction, and communication?

\section{Methods}

The participants. This article is based on a quantitative crosssectional study performed between 2016 and 2017 on 601 patients (55-93 years of age) who were treated at the Ana Aslan National Institute of Gerontology and Geriatrics.

The patients in this study do not have severe pathology and are hospitalized in this institute approximately once, twice a year for regular treatments, as well as for cures with a product with effects that slow down the aging process. The institute belongs to the Ministry of Health, all treatments being settled by the Health Insurance Houses. Specialized medical assistance, scientific research with clinical profile in laboratories of aging biology and social gerontology are carried out here (Ministerul Sănătății, 2018). For those who want, there are also private sections where hospitalization, medical procedures, etc. are paid. The treatment is based on the discovery of Ana Aslan, presented in 1956, at the Therapiewoche Congress in Karlsruhe and then at the European Congress of Gerontology in Basel, being intended to prevent and slow down cellular aging. As the use of the trade name of drugs is not recommended, I will only say that the active substance of the 
drug is procaine (synthesized by Alfred Einhorn in 1905 and introduced in medical practice as a prototype of local anesthetics) (Georgescu et al., 2005). Further research has shown that procaine and other constituents of the drug used (oral and/or injectable) in patients hospitalized at the Ana Aslan Institute have antioxidant action. Treatment has been shown to be effective against age-specific diseases, such as cardiovascular disease, osteoarthritis, chronic rheumatism or nervous system disorders (Revnic et al., 2016a; Revnic et al., 2016b). This product is not a nutritional supplement, it is approved according to national procedures harmonized with those of the European Union, it is sold only by prescription and the treatment is done under medical supervision even at home.

The main diagnostic categories of the respondents included in the study were: cardiovascular diseases (e.g., hypertension, ischemic heart disease, atherosclerosis), rheumatic and musculoskeletal diseases (e.g., osteoarthritis, gonarthrosis, spondylosis), depressive disorder, mild cognitive disorders. Non-cooperative people and individuals with strong auditory or visual sensory deficits, severe cognitive deficits, or disorders accompanied by psychotic elements with serious somatic pathology were excluded from the interviews. Informed written consent was obtained from each participant at the time of recruitment. The subjects were informed that they could withdraw from the study at any stage, and confidentiality was assured. The study was approved by the Ethics Commission of the "Francisc I. Rainer" Anthropology Institute of the Romanian Academy, (Nr. 153/01-03-2016).

Instruments, statistical analyses. Several questionnaires were administered, including personality, depression, memory, quality of life, family, and an omnibus-type questionnaire, with 36 items that collected socio-demographic data, violence, health, and other themes. The questionnaires were completed in the form of faceto-face interviews with each patient. These interviews were conducted by a psychologist. The response rate was $100 \%$. Further information regarding the structure of the sample and the research methodology can be found in other articles resulting from this research (Rada, 2018a; Rada 2018b).

This study explores the answers from one item in the omnibus questionnaire, namely:

How often did the partner express anger, displaying the following types of behavior? (man-on-women, woman-on-man) (1) insults, swearing, humiliation; (2) being forced to engage in unwanted sexual intercourse; (3) withholding sexual activity or affection; (4) slapping, kicking, pushing; (5) hitting with a stick or other objects; (6) threatening with a knife or firearm; and (7) financial control, neglect, food deprivation. Response options were never, occasionally, or often.

Owing to good psychometric qualities, as well as to the fact that they were translated and validated in several countries, the FCS developed by Olson and Barnes (1995) and the FSS developed by Olson (1995) were chosen for this study. These scales were validated on the Romanian population (Rada, 2017; Rada, 2019) The FCS and FSS, each with 10 items, belong to the FACES IV Package, which also contains six scales from the Family Adaptability and Cohesion Scale IV (FACES IV), with 42 items. The answers are given on a five-point Likert scale. FCS had the following response variants: Strongly Disagree, Generally Disagree, Undecided, Generally Agree, and Strongly Agree. Family communication is defined as the act of making information, ideas, thoughts and feelings known among members of a family unit. Family communication can range from poor to very effective" (Olson and Barnes, 1995).

The FSS had the following response variants: Very Dissatisfied, Somewhat Dissatisfied, Generally Satisfied, Very Satisfied, and
Extremely Satisfied. Family satisfaction is defined as the degree to which family members feel happy and fulfilled with each other. The operational definition includes the three dimensions that are related to the Circumplex Model-cohesion, flexibility and communication. So items in the family satisfaction scale assess the satisfaction in all three of these dimensions" (Olson, 1995). Widowed, divorced, and unmarried people had to describe the last relationship.

Using the SPSS software, we summed each of the ten items in the FCS and FSS and provided a total raw score and percentile score for these two scales, in compliance with the manual and the recommendations of the author who created this instrument (Olson, 2010).

Cronbach's alpha values for Communication and Satisfaction were very good (0.91 and 0.94 , respectively). Pearson's Chisquared test was performed using the SPSS statistical program (IBM Corp, 2011).

\section{Results}

Table 1 summarizes the basic socio-demographic variables of the sample population.

Prevalence of types of IPV. The distributions of the manifestation of the seven types of violent behavior are shown in Table 2. This behavior was categorized as follows: emotional or psychological violence (insults, swearing, humiliation); sexual violence (being forced to engage in sexual intercourse or unwanted sexual fantasies), withholding sexual activity or affection; physical violence (slapping, kicking, pushing); hitting using a stick or other objects; threatening with a knife or firearm; and financial

\begin{tabular}{|c|c|c|}
\hline Socio-demographic data & $\mathbf{N}$ & $\%$ \\
\hline \multicolumn{3}{|l|}{ Gender } \\
\hline Female & 492 & 81.9 \\
\hline Male & 109 & 18.1 \\
\hline \multicolumn{3}{|l|}{ Age groups (years) } \\
\hline $55-64$ & 224 & 37.3 \\
\hline $65-74$ & 272 & 45.3 \\
\hline $75-79$ & 70 & 11.6 \\
\hline $80+$ & 35 & 5.8 \\
\hline \multicolumn{3}{|l|}{ Place of residence } \\
\hline Urban & 445 & 74.0 \\
\hline Rural & 156 & 26.0 \\
\hline \multicolumn{3}{|l|}{ Marital status } \\
\hline Married & 318 & 52.9 \\
\hline Widowed & 202 & 33.6 \\
\hline Divorced & 55 & 9.2 \\
\hline Consensual union over 1 year & 19 & 3.2 \\
\hline Unmarried (single) & 7 & 1.1 \\
\hline \multicolumn{3}{|l|}{ School education } \\
\hline $\begin{array}{l}\text { Elementary/high school (up to } 12 \text { years of } \\
\text { school) }\end{array}$ & 167 & 27.8 \\
\hline Lyceum/ school of foreman in a profession & 305 & 50.7 \\
\hline University degree & 129 & 21.5 \\
\hline \multicolumn{3}{|l|}{ Personal monthly incomea } \\
\hline Less or equal to 215 EUR & 224 & 37.3 \\
\hline $216-429$ & 289 & 48.1 \\
\hline $430-644$ & 57 & 9.5 \\
\hline $645-858$ & 13 & 2.2 \\
\hline Over 858 EUR & 18 & 2.9 \\
\hline
\end{tabular}


Table 2 Prevalence of the seven manifestations of violence in the couple.

\begin{tabular}{|c|c|c|c|c|c|}
\hline & \multirow{2}{*}{$\begin{array}{l}\text { Manifestation of violent } \\
\text { behavior }\end{array}$} & \multicolumn{2}{|c|}{ Never } & \multicolumn{2}{|c|}{ Occasionally, often } \\
\hline & & $\mathbf{N}$ & $\%$ & $\mathbf{N}$ & $\%$ \\
\hline 1 & Insults, swearing, humiliation & 439 & 73.0 & 162 & 27.0 \\
\hline 2 & $\begin{array}{l}\text { Being forced to engage in } \\
\text { unwanted sexual intercourse }\end{array}$ & 575 & 95.7 & 26 & 4.3 \\
\hline 3 & $\begin{array}{l}\text { Withholding sexual activity or } \\
\text { affection }\end{array}$ & 530 & 88.2 & 71 & 11.8 \\
\hline 4 & Slapping, kicking, pushing & 565 & 94.0 & 36 & 6.0 \\
\hline 5 & $\begin{array}{l}\text { Hitting with a stick or other } \\
\text { objects }\end{array}$ & 579 & 96.3 & 22 & 3.7 \\
\hline 6 & $\begin{array}{l}\text { Threatening with a knife or } \\
\text { firearm }\end{array}$ & 586 & 97.5 & 15 & 2.5 \\
\hline 7 & $\begin{array}{l}\text { Financial control, neglect, food } \\
\text { deprivation }\end{array}$ & 569 & 94.7 & 32 & 5.3 \\
\hline
\end{tabular}

Table 3 Prevalence of the seven manifestations of violence in the couple by gender.

\begin{tabular}{|c|c|c|c|}
\hline \multirow[t]{2}{*}{ Types of abuse, violence } & \multirow{2}{*}{$\begin{array}{l}\text { Frequency of } \\
\text { manifestation }\end{array}$} & \multicolumn{2}{|c|}{ Gender } \\
\hline & & Male & Female \\
\hline \multirow[t]{2}{*}{ Insults, swearing, humiliation } & Never & 19.6 & 80.4 \\
\hline & Occasionally, often & 14.2 & 85.8 \\
\hline \multirow[t]{2}{*}{ Slapping, kicking, pushinga } & Never & 19.1 & 80.9 \\
\hline & Occasionally, often & 2.8 & 97.2 \\
\hline \multirow{2}{*}{$\begin{array}{l}\text { Being forced to engage in } \\
\text { unwanted sexual intercourse }\end{array}$} & Never & 18.3 & 81.7 \\
\hline & Occasionally,often & 15.4 & 84.6 \\
\hline \multirow{2}{*}{$\begin{array}{l}\text { Withholding sexual activity or } \\
\text { affection }\end{array}$} & Never & 17.2 & 82.8 \\
\hline & Occasionally, often & 25.4 & 74.6 \\
\hline \multirow{2}{*}{$\begin{array}{l}\text { Hitting with a stick or other } \\
\text { objects }\end{array}$} & Never & 18.7 & 81.3 \\
\hline & Occasionally, often & 4.5 & 95.5 \\
\hline \multirow{2}{*}{$\begin{array}{l}\text { Financial control, neglect, food } \\
\text { deprivation }\end{array}$} & Never & 18.6 & 81.4 \\
\hline & Occasionally, often & 9.4 & 90.6 \\
\hline \multirow{2}{*}{$\begin{array}{l}\text { Threatening with a knife or } \\
\text { firearm }\end{array}$} & Never & 18.3 & 81.7 \\
\hline & Occasionally, often & 13.3 & 86.7 \\
\hline
\end{tabular}

abuse or neglect (deprivation) (financial control, neglect, food deprivation).

Thus, at least one of the seven types of violence were identified in 199 (33.1\%) respondents. By restricting the seven types of violence in four categories according to the above methodology, it was identified that at least one of the two behaviors belonging to the sexual violence category occurred in $88(14.6 \%)$ of respondents and at least one of the three behaviors belonging to the category of physical violence occurred in $43(7.2 \%)$ respondents.

In all manifestations of couple violence, the number of women reporting that they were victims was higher than the number of men. However, the manifestation of couple violence was significantly different only in the case of slapping, kicking, and pushing, where the percentage of women who reported them from their partner Occasionally or often was significantly higher than the percentage of men: $97.2 \%$ vs. $2.8 \%$ (Table 3 ).

Of those who reported manifestations of violence Occasionally or Often in couples, more than $70 \%$ were living in urban areas. We detected no significant differences between the data of rural and urban areas.

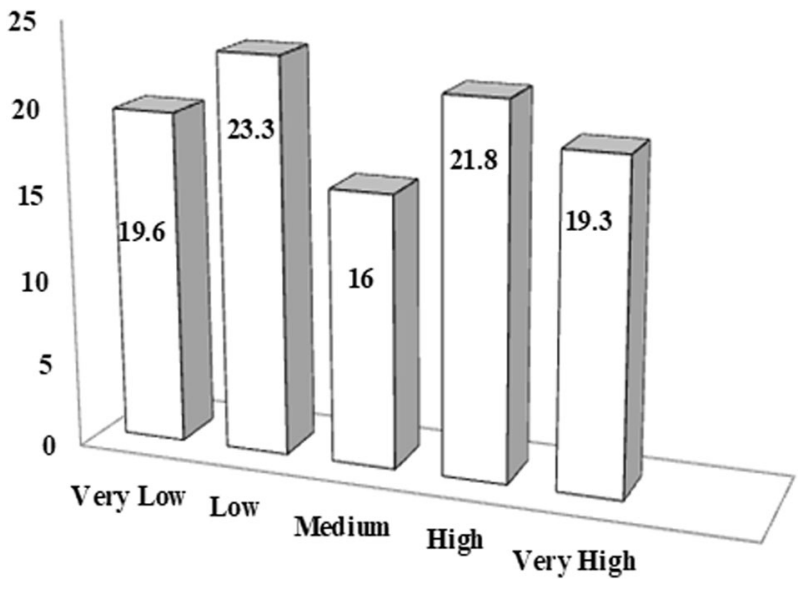

Fig. 1 Level of family communication.

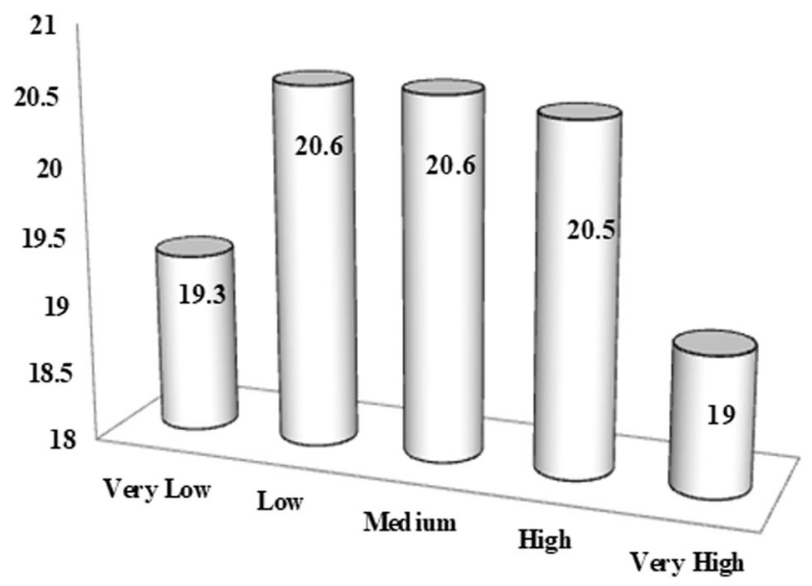

Fig. 2 Level of family satisfaction.

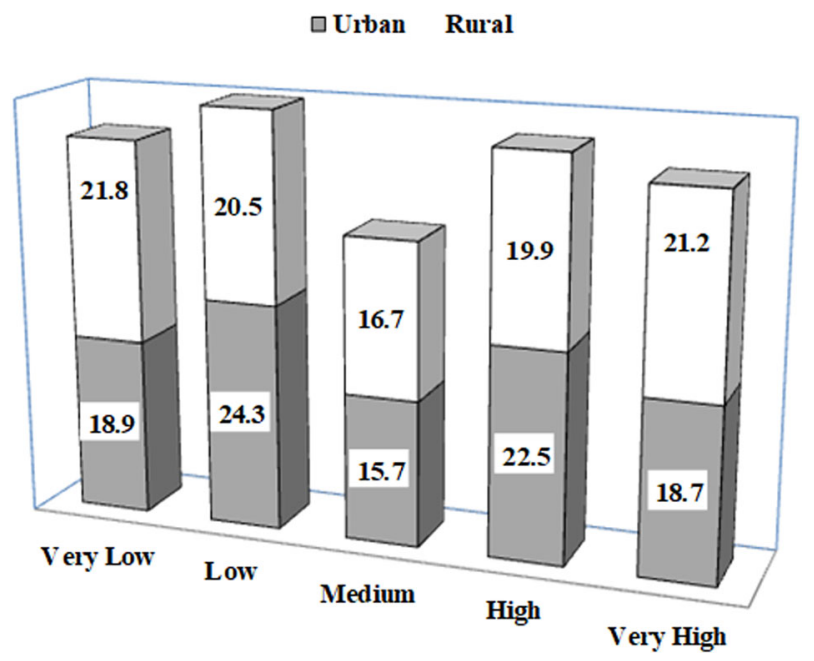

Fig. 3 Level of family communication by residence environment.

Family communication and satisfaction. The levels of family communication and satisfaction are presented in Figs. 1 and 2.

Regarding the levels of communication in the family, the statistical differences were not significant by gender (Pearson ChiSquare $=2.406, \mathrm{df} .=4, p=0.662$ ) and by residence environment $($ Pearson Chi-Square $=1.997, \mathrm{df} .=4, p=0.736)($ Figs. 3 and 4$)$. 


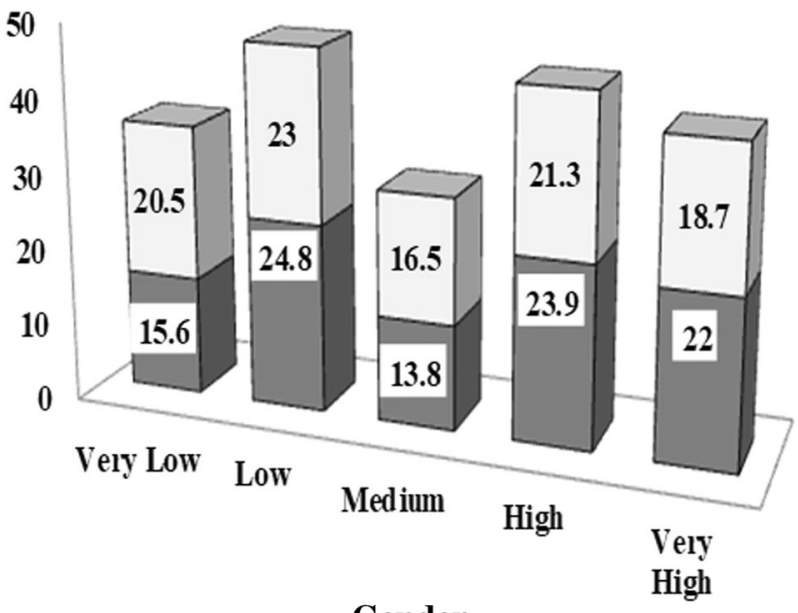

Gender

Fig. 4 Level of family communication by gender.

Also the levels of family satisfaction in the family, the statistical differences were not significant by gender (Pearson ChiSquare $=4.258, \mathrm{df} .=4, p=0.372$ ) and by residence environment $($ Pearson Chi-Square $=9.434, \mathrm{df} .=4, p=0.051)($ Figs. 5 and 6).

The manifestation of couple violence according to family communication level and family satisfaction level. Table 4 shows that the rate at which violence was Never manifested was higher in families where communication was High and Very High. At the same time, the difference in the manifestation of violence according to the level of communication was statistically significantly higher for behaviors such as insults, swearing, humiliation.

Table 5 shows that the rate at which violence was Never manifested was higher in families where satisfaction was High and Very High. At the same time, the difference in the manifestation of violence according to the level of satisfaction in the family was statistically significant in the case of behaviors such as insults, swearing, humiliation, withholding sexual activity or affection, financial control, neglect, and food deprivation.

\section{Discussion}

Prevalence of types of IPV. Methods for collecting data and classifying statistics of IPV are not uniform worldwide; it is, therefore, impossible to conduct an accurate comparison among countries. Comparing data on IPV (domestic violence) among countries is also difficult owing to cultural differences and perceptions of the concept of abuse from one country to another. It was very difficult to find IPV studies performed only on people by 55 years and over. Nevertheless, we can make same comparisons between the present study and other studies.

Ordered according to prevalence, the seven manifestations of domestic violence, with the frequency "occasionally or often" were as follows: insults, swearing, humiliation (first), withholding sexual activity or affection, slapping, kicking, pushing, financial control, neglect, food deprivation, being forced to engage in unwanted sexual intercourse, hitting with a stick or other objects and threatening with a knife or firearm (last).

The seven types of violent behaviors can be categorized in four types of violence as follows: emotional or psychological violence (1-insults, swearing, humiliation); physical violence (3-slapping, kicking, pushing; 4-hitting using a stick or other objects; 5 -threatening with a knife or firearm); sexual violence (2withholding sexual activity or affection; 6 -being forced to engage

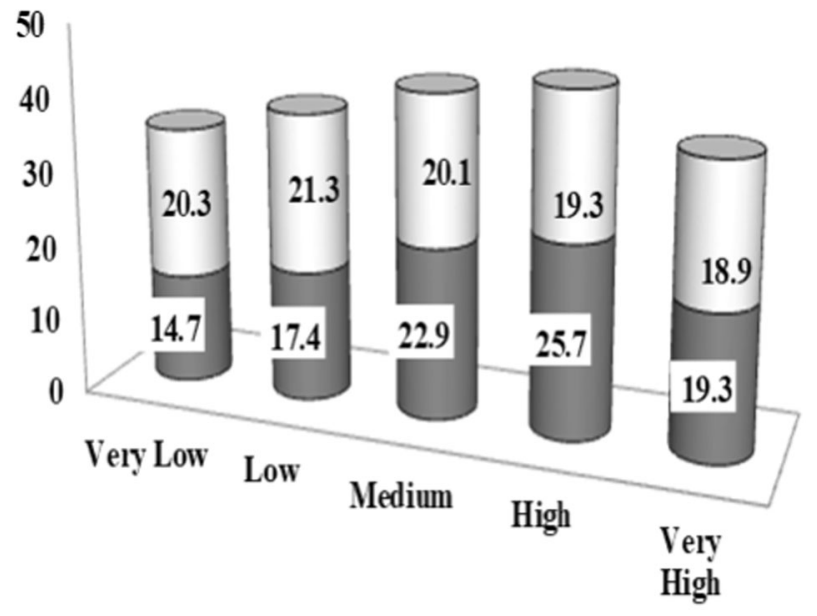

\section{$\square$ Masculin $\square$ Feminin}

Fig. 5 Level of family satisfaction by gender.

\section{- Urban Rural}

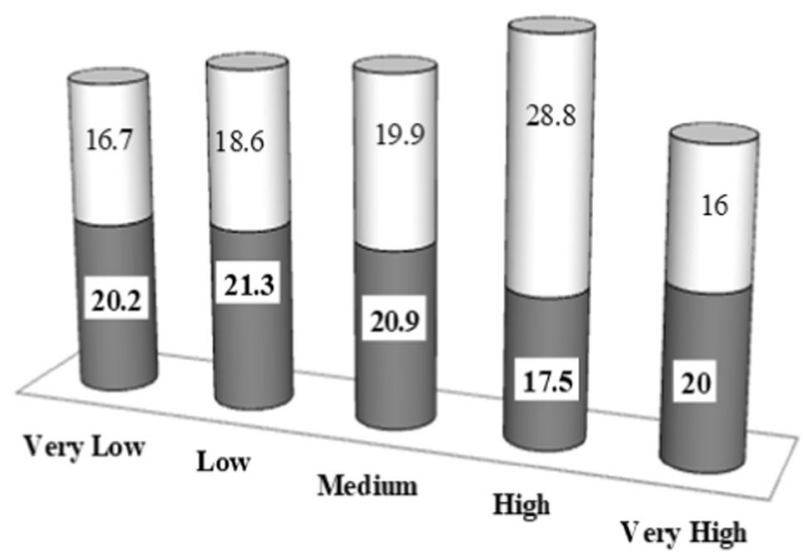

Fig. 6 Level of family satisfaction by residence environment.

in sexual intercourse or unwanted sexual fantasies); and financial abuse or neglect (deprivation) (7-financial control, neglect, food deprivation).

In these circumstances the hierarchy expressed as a percentage of the seven types of violence manifested occasionally or often is the following: (1) emotional or psychological violence-27\%, (2) sexual violence- $16.1 \%$, (3) physical violence $-12.2 \%$, (4) financial abuse or neglect (deprivation)-5.3\%.

A recent study carried out among 836 Romanian young people in a romantic couple relationship, has also shown that, excluding jealousy, the most frequent form of IPV was emotional or psychological violence ("the practice of addressing insulting or humiliating words to each other"). However, the second and third form of IPV were physical violence ("being injured or harmed by the partner"), respectively sexual violence ("being exposed to forced sexual intercourse") (Faludi, 2018).

Here, we found that more than one-quarter of respondents (men and women) suffered occasionally or often from a form of abuse. This is a higher percentage in comparison with the American Study from 2004, which revealed that in the 10 states, $\sim 11 \%$ of the substantiated reports of abuse of persons aged 60 and 
Table 4 Frequency of manifestation of types of violence according to Family communication level.

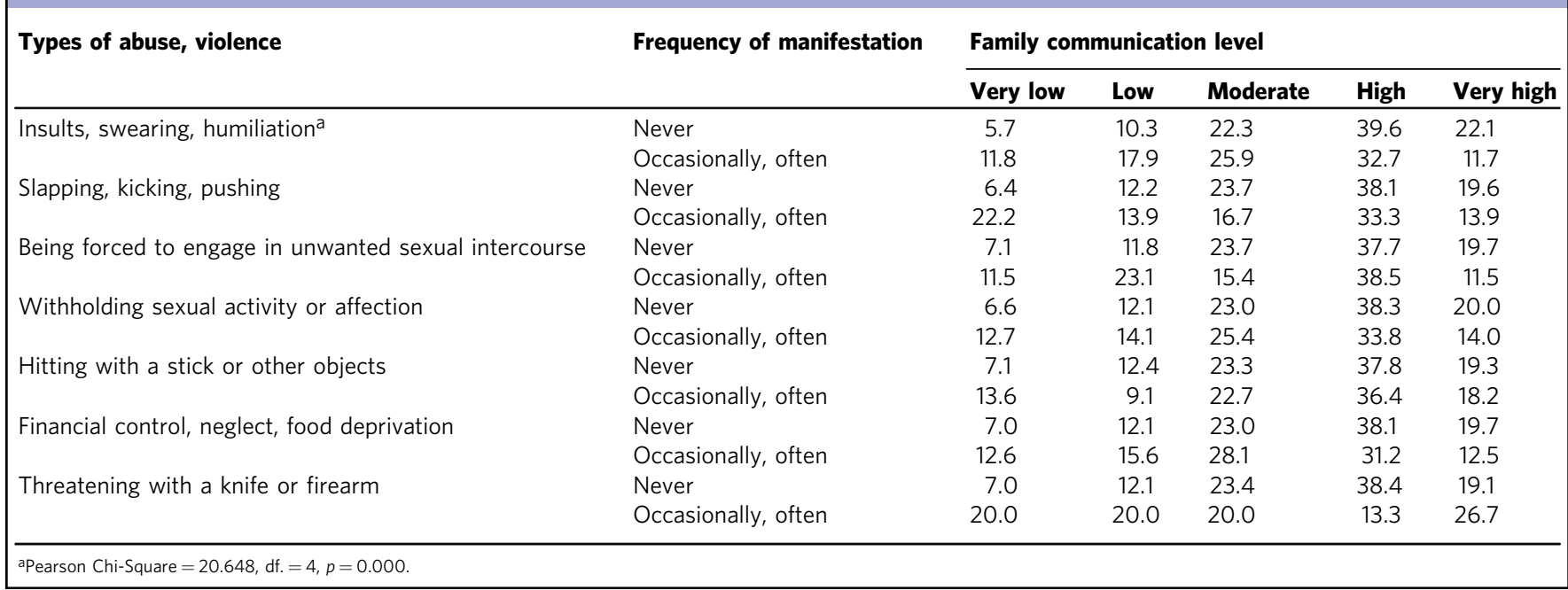

Table 5 Frequency of occurrence of types of violence according to the family satisfaction level.

Types of abuse, violence

Insults, swearing, humiliation ${ }^{a}$

Financial control, neglect, food deprivation ${ }^{\mathrm{c}}$

Slapping, kicking, pushing

Being forced to engage in unwanted sexual intercourse

Hitting with a stick or other objects

Threatening with a knife or firearm
Withholding sexual activity or affection ${ }^{b}$

\section{Frequency of manifestation}

\begin{tabular}{llllll} 
& Very low & Low & Moderate & High & Very high \\
\cline { 2 - 6 } Never & 15.7 & 40.3 & 15.7 & 17.1 & 11.2 \\
Occasionally, often & 29.0 & 43.8 & 13.0 & 4.9 & 9.3 \\
Never & 17.3 & 40.8 & 16.2 & 14.9 & 10.8 \\
Occasionally, often & 33.8 & 45.1 & 5.6 & 5.6 & 9.9 \\
Never & 18.3 & 40.8 & 15.8 & 14.4 & 10.7 \\
Occasionally, often & 37.5 & 50.0 & 0 & 3.1 & 9.4 \\
Never & 18.4 & 41.4 & 14.9 & 14.5 & 10.8 \\
Occasionally, often & 33.3 & 38.9 & 16.7 & 2.8 & 8.3 \\
Never & 19.1 & 41.2 & 14.8 & 14.3 & 10.6 \\
Occasionally, often & 23.2 & 42.3 & 19.2 & 3.8 & 11.5 \\
Never & 19.6 & 40.6 & 15.0 & 14.3 & 10.5 \\
Occasionally, often & 13.7 & 59.1 & 13.6 & 0 & 13.6 \\
Never & 19.1 & 41.0 & 15.2 & 14.1 & 10.6 \\
Occasionally, often & 26.7 & 53.3 & 6.7 & 0 & 13.3 \\
\hline
\end{tabular}

aPearson Chi-Square $=22.542, \mathrm{df} .=4, p=0.000$

bPearson Chi-Square $=16.525, \mathrm{df}=4, p=0.002$.

cPearson Chi-Square $=15.911$, df. $=4, p=0.003$. older with a known perpetrator involved a spouse or intimate partner (Teaster et al., 2006).

The most frequent form of violence includes insults, swearing, and humiliation, which is similar to other studies where emotional abuse appears to be the most common form of IPV in the case of couples of various ages (Karakurt and Silver, 2013; Chuemchit et al., 2018).

Here, we found that more than one-quarter of respondents (men and women) experienced Occasionally or often emotional or psychological violence, which represents a higher percentage in comparison with the American study from 2008 on over 6000 older adults, which estimated that $13.5 \%$ of older adults had suffered emotional abuse since the age of 60 years (Acierno et al., 2008). The proportion of our respondents reporting Occasionally or often emotional or psychological violence abuse is also higher than reported by a WHO-supported study, 28 countries from different regions, and 12 low- and middle-income countries, which revealed that almost $16 \%$ of people aged 60 years and older were subject to psychological abuse. Also, the rates of sexual and physical abuse in the current research were higher than those reported in the same WHO-supported study (World Health Organization, 2017; Yon et al., 2017). In the medical literature, the most frequently identified form of abuse is physical (as it is harder to hide; it is visible and sometimes requires hospitalization) (Ilie et al., 2017).

At a high distance, the second form of violence experienced Occasionally or often was sexual violence (withholding sexual activity or affection, being forced to engage in unwanted sexual intercourse).

The rate of sexual violence in the current research was higher than reported in an American study including 9086 females and 7421 males (Black et al., 2011).

Sexual violence is usually perpetrated by the male partner (husband), but in some cases may be committed by the female partner. Sex without the consent of the partner is as disturbing as that with a stranger (Parkinson, 2017). Sexual abuse between spouses, especially admitting the idea of sexual abuse induced by a husband on a wife, is something recent in Romania. This is because of the traditional patriarchal mentality that was present until 1989 when the communist regime ended. In a research 
based on semi-structured in-depth interviews carried out in 2013 with health practitioners, Rujoiu and Rujoiu (2014) emphasized that some women do not realize that they were abused because they consider that the sexual intercourse becomes an obligation once married and women think that they must have sexual intercourse whenever their husbands decide. For this reason we consider that sexual abuse is under-reported.

In compliance with Art. 218 in the Romanian penal code, rape is defined as:

"the sexual intercourse, oral or anal with a person, accomplished by coercion, by rendering the victim not able to defend or to express his or her will, or by taking advantage of this state, and is punished with imprisonment from 3 to 10 years and with the prohibition of the exercise of certain rights."

According to Art. 219, sexual aggression is defined as:

"act of sexual nature, other from those mentioned in art. 218 with a person, accomplished by coercion, by rendering the victim not able to defend or to express his or her will, or by taking advantage of this state, and is punished with imprisonment from 2 to 7 years and with the prohibition of the exercise of certain rights."

The penal act for these offenses is triggered by the complaint of the victim (Monitorul Național Nr. 389, 2016).

In the third place, as percentage, was physical violence (slapping, kicking, pushing, hitting using a stick or other objects, threatening with a knife or firearm).

For comparison, although the survey questions were different, the survey of family violence in Canada found that $1 \%$ of older people had experienced physical abuse or sexual assault by children, carers or partners in the last 5 years (Canadian Center for Justice Statistics, 2002). In this study performed among middle-aged adults and older people in Romania, the share was much higher.

Physical violence receives greater attention since it is frequently accompanied by official evidence (e.g., doctor's and police reports) and it tends to be considered "out in the open". Less attention received the psychological and sexual abuse because it is not easy to identify at first sight.

Physical violence or other forms of abuse are almost always accompanied by insults, swearing and humiliation as for example psychological abuse, which should also be taken into account by a doctor when prescribing psychological and/or psychiatric treatment. Almost any person will react with difficulty to the treatment for another disease when this is associated with depression or anxiety, especially in the case of older people, where those $>65$-years-old are twice as likely to die compared with younger patients with a similar injury severity score (ReskeNielsen and Medzon, 2016).

In this study, the rate of domestic violence reported by women from the partner (husband) was higher than that reported by men from partner (wife), which is similar to the results of Gass et al. in South Africa on 1715 married or cohabiting adults (Gass et al., 2010) and similar to what was reported in the 2015 Crime Survey for England and Wales: among adults aged 16 to 59 years, women in the UK experiencing twice as much domestic abuse (relative to men) during their lifetime (Office for National Statistics, UK, 2015).

The results of our study are similar to those reported by Stöckl et al. in a systematic search of five databases, and a survey of official sources of 169 countries (i.e., the experience of being subject to domestic violence was greater among women than among men) (Stöckl et al., 2013). Morover, we should consider the fact that the analysis referred to a number or proportion of women or men who were murdered by an intimate partner.
In this research, although more women than men reported that they were subject to at least one form of violence, this difference was statistically significant only for slapping, kicking, and pushing. The results of our study are similar to those obtained in the research funded by the EU Commission, which concluded that men and women generally experienced domestic violence as both victims and perpetrators, with few significant sex-differences (Costa et al., 2015).

There is a common stereotype that women are the victims and men are the aggressors. Most of the men can be victims of violence by their spouses. Some men may not report the abuse because of the shame, in the sense that this would damage their image of masculinity.

The results of the current study are different from those suggested by Houry et al., who reported similar rates of perpetration and victimization in men and women (Houry et al., 2008).

Faludi (2018) found that among the Romanian young people in a couple relationship, men reported significantly higher levels of IPV than women, for each investigated form of violence: psychological violence $(46.6 \%$ vs. $38.3 \%)$; physical violence ( $9.9 \%$ vs. $4.4 \%$ ); and sexual violence ( $7.6 \%$ vs. $2.4 \%)$. The author provided two possible explanations for such an unexpected result: women might have under-declined the violent behaviors of their partner, while men might have exaggerate the manifestation of violence in their romantic couple; or, a change in the pattern of sexuality could have emerged among young people in Romania, with a weakening of the double-standard model for women and an increase of women's control over sexuality in the couple relationship.

More studies are necessary to clarify the connection between gender and the type of violence. Some studies suggest that, in the case of minor violence, women are as violent as men, but regarding serious violence with lesions, men are more violent (Stets and Straus, 1990; Canadian Center for Justice, 2016).

Family communication and satisfaction. The participants were relatively evenly distributed across the levels of communication very low, low, high, and very high, with the fewest being categorized into the medium communication category (Fig. 1). Among our sample of middle-aged and older subjects, communication was moderate or better for more than a half. The participants were evenly distributed across all levels of family satisfaction (Fig. 2). In this regard, we can state that in this sample, satisfaction was moderate and beyond for $>60 \%$, which shows a relatively good potential of the couples. Consequently, it can be suggested that this similarity regarding the level of family communication and satisfaction shows that satisfied couples engage in better quantitative and qualitative communication, efficient both quantitatively and qualitatively. This point was also noted by Farah and Aneesh (2018) in the Indian study on 50 couples between 20 and 50 years, with up to 30 years of marriage, which revealed a positive correlation between marital satisfaction and communication.

There are studies that show that marital satisfaction is not only about the ability to communicate but is influenced by other variables, such as the number of children, the number of years of marriage, the life cycle of the partners, the level of income, the level of education, and health, among others (Korporaal et al., 2013; Zhang et al., 2016).

In a study that investigated the satisfaction with intimate life among 800 Romanian cancer patients aged 18 to 82 years, it has been proved that participants who perceived they had a good health were much more protected from being exposed to lack of satisfaction with their intimate life than those who reclaimed a 
bad health. Also, closeness to partner played the prevailing role in the perception of intimacy among Romanian cancer patients. However, as expected, the participants aged 65 and over were significantly more exposed to dissatisfaction with intimate life than the younger categories (Faludi and Dégi, 2016).

Anahita et al. (2016) in a study including 400 older adults from Iran (mean age, $65.2 \pm 5.7$ years), revealed that older people were in the high satisfaction range. Other authors have reported that age and marriage years do not influence marital satisfaction and communication (Farah and Aneesh, 2018). In the current study, gender, age group, and residence did not significantly influence the family communication and satisfaction. A possible explanation may be that in older people there is a relative homogenization regarding the couple relationships, a renunciation at the competitive interaction model, more frequent in young couples. At the same time, the internal urban-rural migration as well as the free movement outside the borders (allowed in Romania after 1989, when the Ceausescu communist totalitarian regime fell) could influence the pattern of manifestation of communication and family satisfaction.

Links between violence, satisfaction, and communication within couple. When the level of communication was very low and low, the rate of occurrence (occasionally or often) of all the forms of violence was higher, reaching statistical significance in the case of insults, swearing, humiliation.

When family satisfaction was very low or low, the rate of occurrence (occasionally or often) of all the forms of violence was higher, reaching statistical significance in the case of insults, swearing, humiliation, withholding sexual activity or affection, financial control, neglect, and food deprivation. Thus, we can state that in the case of the forms of violence occurring at the highest rates, family communication and satisfaction were statistically significantly affected.

The connections between IVP and FSS and FCC were emphasized. In the future, other variants that can influence the reports on violence should also be taken into account. Thus, in an American study, Iveniuk et al. used national data for 2010-2011 from 955 older couples (married or in cohabitation) and found that the wives with husbands with poor or bad physical health tended to report high levels of marital conflict, but it is interesting that the reverse was not true (Iveniuk et al., 2014).

The current study identified an association between low family satisfaction and being a victim of violence from the partner and found that this association was stronger in the case of women for the category of emotional or psychological violence (insults, swearing, humiliation). This result is in line with that of an American study conducted in 2007 (representative at the national-level, including young people aged 24-32-years-old, married or in a romantic relationship), which revealed that the association between the satisfaction in the relationship and being a victim of the violence from the partner was stronger for women than for men (Ackerman and Field, 2011).

\section{Conclusions}

Like other authors, we believe that it is difficult to depict the prevalence of IPV experienced by older persons because they are typically not studied as a separate group (Payne, 2008). Most studies address IPV towards all women, without discriminating among age groups.

The problem of couple violence among older people is more complicated because they are sometimes overwhelmed by serious health issues and have to become the caretakers of the spouse. In certain situations, they use coercion to force them to take a bath or to calm them down, as may happen in the case of Alzheimer's disease suffers (Roberto et al., 2013; Rada, 2018b).

Our study on a Romanian sample made up of couples in middle adulthood and older people revealed the following:

- IPV prevalence was generally high, especially for the categories of insults, swearing, humiliation, withholding sexual activity, and affection. More women than men reported IPV, especially insults, swearing and humiliation.

- The potential of family communication and satisfaction is relatively good, and these are associated.

- In the case of low and very low family communication and satisfaction, IPV prevalence was higher for all categories, mainly for the forms of violence occurred at the highest rates: insults, swearing, humiliation, slapping, kicking and pushing, withholding sexual activity or affection, financial control, neglect, and food deprivation.

Violence between partners destroys the relationship and the intimacy between spouses. This aspect raised the question: how is it possible that spouses continue to remain together in the case of lack of communication, family satisfaction, low attachment? In this study, the situation may be chronic because the couples questioned about the abuse during their lifetime were in middle adulthood and older people and had many years of marriage. The general attachment, but especially emotional attachment in the case of the older couples, can contribute to remaining in an unhealthy, violent relationship. A decline of the financial situation, fewer social relationships after retirement, and health issues might also contribute to resignation regarding such a relationship.

The current study emphasizes that there is a vicious circle because, on the one hand, violence can provoke emotional distance, and on the other hand, a lack of intimacy and communication can lead to violence. At the same time, low satisfaction in a relationship can be seen both as a cause and as an effect of violence.

Psychotherapy or counseling is necessary to modify the patterns of interactions between partners, to improve communication and negotiation abilities, thereby solving the problems and the potential conflicts in a healthy manner, without anger, despise, physical or verbal aggression, and to strengthen thus the couple relationships. This is particularly important in the case of older couples who can better face the losses and disabilities associated with old age and who have specific needs for company, encouragement, and support.

Even if the level of physical violence is lower, its health consequences can be serious among the older people. Doctors should be more attentive because certain gastrointestinal disorders, pains, cardiac diseases, or other somatic or psychologic issues can arise from violence from the partner or unsatisfactory communication/relationship, especially as the voices of the older women and men are more timid and muffled.

The programs and information materials of campaigns addressing family violence are rarely aimed at people in middle adulthood or older people and are instead focused on young women and children. We believe this imbalance should be redressed.

Limitations. The main limitation of this study is the small sample size, which was unbalanced in structure. This study did not include a representative sample, and we are, therefore, unable to generalize our results. No data were collected regarding other risk factors of violence within families, such as alcohol or drug abuse, inability to resolve social problems, certain diseases, and others. However, our findings are useful as a starting point when designing policies to prevent violence among middle-aged adults 
and older people and emphasizing the importance of satisfaction and communication within couples.

\section{Data availability}

The datasets generated during and/or analyzed during the current study are not publicly available because the institutions involved in this study did not provide a public archive within the project but are available from the corresponding author on reasonable request.

Received: 14 November 2019; Accepted: 4 September 2020;

Published online: 29 September 2020

\section{References}

Acierno R, Resnick H, Kilpatrick D, Boyle J, Steve K, Muzzy W (2008) National Elder Mistreatment Study. Ann Arbor, MI [United States]: Inter-university Consortium for Political and Social Research [distributor]. Retrieved $13 \mathrm{Feb}$, 2013, from https://doi.org/10.3886/ICPSR28561.v1

Ackerman J, Field L (2011) The gender asymmetric effect of intimate partner violence on relationship satisfaction. Violence Vict 26(6):703-724. https://doi. org/10.1891/0886-6708.26.6.703. Retrieved 1 Mar, 2019

Adebowale AS (2018) Spousal age difference and associated predictors of intimate partner violence in Nigeria. BMC Public Health 18(1):2-12. https://doi.org/ 10.1186/s12889-018-5118-1. Retrieved 17 Feb, 2019

Agenția Națională pentru Egalitatea de Şanse între Femei şi Bărbați [National Agency for Equal Opportunities for Women and Men] (2018a) Retrieved 11 Feb, 2019, from http://anes.gov.ro/egalitatea-de-sanse-intre-femei-si-barbati/

Agenția Națională pentru Egalitatea de Şanse între Femei şi Bărbați [National Agency for Equal Opportunities for Women and Men] (2018b) Legislaţie națională-Violența în familie [National Legislation-Family Violence]. Retrieved $11 \mathrm{Feb}, 2019$, from http://anes.gov.ro/legislatie-nationala-egalitateade-sanse/

Agenția pentru Drepturi Fundamentale a Uniunii Europene Schwarzenbergplatz Vienna-Austria (FRA) (2017) Violența împotriva femeilor:o anchetă la nivelul UE, rezultatele pe scurt. [European Union Agency for Fundamental Rights Schwarzenbergplatz Vienna-Austria, Violence Against Women: An EU Survey, results in brief]. Retrieved $10 \mathrm{Feb}, 2019$, from http:// violentaimpotrivafemeilor.ro/wp-content/uploads/2015/06/Violentaimpotriva-femeilor-ancheta-FRA.pdf

Anahita TB, Sadat IA, Fini IA (2016) The marital satisfaction and its relative factors among older adults. Nurse Care Open Acces J 1(4):63-67. https://doi. org/10.15406/ncoaj.2016.01.000

Archer J (2000) Sex differences in aggression between heterosexual partners: A meta-analytic review. Psychol Bull 126(5):651-680. https://doi.org/10.1037/ 0033-2909.126.5.651

Avon împotriva violenței domestice (2013) [Avon against domestic violence]. Retrieved 8 Feb, 2019, from http://campaniarespectului.ro/campaniarespectului/implicarea-noastra/implicarea-noastra1/2013

Black MC, Basile KC, Breiding MJ, Smith SG, Walters ML, Merrick MT,... Stevens MR (2011) The National Intimate Partner and Sexual Violence Survey (NISVS): 2010 Summary Report. National Center for Injury Prevention and Control, Centers for Disease Control and Prevention, Atlanta, GA. Retrieved 25 Feb, 2020, from https://www.cdc.gov/violenceprevention/pdf/nisvs_report2010-a.pdf

Bonnet F (2015) Violences conjugales, genre et criminalisation: synthèse des débats américains. Revue française de sociologie 56(2):357-383. https://doi.org/ $10.3917 /$ rfs.562.0357

Breiding MJ, Basile KC, Smith SG, Black MC, Mahendra RR (2015) Intimate partner violence surveillance: uniform definitions and recommended data elements, version 2.0. Atlanta, GA: National Center for Injury Prevention and Control, Centers for Disease Control and Prevention. Retrieved 25 Feb, 2020, from https://www.cdc.gov/violenceprevention/pdf/intimatepartnerviolence.pdf

Bunker-Hellmich LA (2015) The demographics of an aging population. Retrieved 8 Aug, 2018, from https://www.healthdesign.org/insights-solutions/demographicsaging-population

Canadian Center for Justice Statistics (2002) Family violence in Canada: a statistical profile 2002. Retrieved 29 Mar, 2020, from http://www.fact.on.ca/Info/dom/ stat2002.pdf

Canadian Centre for Justice Statistics (2016) Family violence in Canada: A statistical profile, 2014. Retrieved 28 Mar, 2020, from https://www150.statcan.gc. $\mathrm{ca} / \mathrm{n} 1 / \mathrm{pub} / 85-002-\mathrm{x} / 2016001 /$ article/14303-eng.pdf

Centrul de Sociologie Urbană și Regională CURS (2008, Aprilie) Violența domestică în România, Ancheta sociologică la nivel national Martie-Aprilie 2008 [Center for Urban and Regional Sociology CURS, Domestic Violence in
Romania, Sociological Survey at National Level March-April 2008]. Retrieved $10 \mathrm{Feb}, 2019$, from https://transcena.ro/wp-content/uploads/Violentadomestica-in-Romania-ancheta-sociologica-2008.pdf

Chuemchit M, Chernkwanma S, Rugkua R, Daengthern L, Abdullakasim P, Wieringa SE (2018) Prevalence of intimate partner violence in Thailand. J Fam Violence 33(5):315-323. https://doi.org/10.1007/s10896-018-9960-9

Costa D, Soares J, Lindert J, Hatzidimitriadou E, Sundin Ö, Toth O, Barros H (2015) Intimate partner violence: a study in men and women from six European countries. Int J Public Health 60(4):467-478. https://doi.org/ 10.1007/s00038-015-0663-1

Dutton D, Nicholls T (2005) The gender paradigm in domestic violence research and theory: Part 1-The conflict of theory and data. Aggress Violent Behav 6:680-714. https://doi.org/10.1016/j.avb.2005.02.001

English Oxford Living Dictionaries. Middle age. (2018) http://www. oxforddictionaries.com/us/definition/american_english/middle-age. Retrieved 9 Jan, 2018

Faludi C (2018) Consequences of intimacy and violence in the couple relationships of young romanians on their future life plans. In: de Montlibert C, Zamfira A, Radu D (eds) Gender in focus: identities, codes, stereotypes and politics. Barbara Budrich Publishers, Berlin \& Toronto. pp. 226-249

Faludi C, Dégi CL (2016) Psycho-social predictors of satisfaction with intimate life in Romanian cancer patients. Cogn Brain Behav 20(4):239-257

Farah H, Aneesh K (2018) Marital satisfaction and communication skills among married couples. Indian J Soc Res 59(1):35-44

Fundația Sensiblu (2015) Campanii sustinute de Fundatia Sensiblu [Campaigns supported by the Sensiblu Foundation]. Retrieved 8 Feb, 2019, from http:// www.fundatiasensiblu.ro/campanii/2015-2/

Gass JD, Stein DJ, Williams DR, Seedat S (2010) Gender differences in risk for intimate partner violence among South African adults. J Interpers Violence 26(14):2764-2789. https://doi.org/10.1177/0886260510390960. Retrieved 25 Feb, 2019

Georgescu M, Rusu C, Revnic F, Rachita M, Lupeanu E, Valuch A, Andrei V, Gradinaru D, Borsa C, Ionescu C, Opris S (2005) Gerovital H3 și Aslavital-mecanismegeroprotectoare şi antioxidante la nivel celular şi moleculară [Gerovital H3 and Aslavital-geroprotective and antioxidant mechanisms at the cellular and molecularlevel]. Rom J Geront Geriatr 26 (4):27-45

Houry D, Rhodes KV, Kemball RS (2008) Differences in female and male victims and perpetrators of partner violence with respect to WEB scores. J Interpers Violence 23(8):1041-1055. https://doi.org/10.1177/0886260507313969

IBM Corp (2011) IBM SPSS statistics for windows, version 20.0. IBM Corp, Armonk, NY

Ilie AC, Pîslaru AI, Alexa ID, Pancu A, Gavrilovici O, Dronic A (2017) The psychological abuse of the elderly-a silent factor of cardiac decompensation. Maedica 12(2):119-122

INSCOP Research (2013) Barometrul de opinie publică-Adevărul despre România" Violenta domestică, 2013 [Barometer of public opinion - The truth about Romania. Domestic violence]. Retrieved $25 \mathrm{Mar}, 2020$, from http:// www.inscop.ro/wp-content/uploads/2013/08/INSCOP.-Iul.2013.-Violentadomestica.pdf

Iveniuk J, Waite LJ, McClintock MK, Teidt AD (2014) Marital conflict in older couples: Positivity, personality, and health J Marriage Fam 76(1):130-144. https://doi.org/10.1111/jomf.12085

Karakurt G, Silver KE (2013) Emotional abuse in intimate relationships: the role of gender and age. Violence Vict 28(5):804-821

Korporaal M, van Groenou MIB, van Tilburg TG (2013) Health problems and marital satisfaction among older couples. J Aging Health 25(8):1279-1298. https://doi.org/10.1177/0898264313501387. Retrieved 1 Mar, 2019

Kwak M, Park S, Ingersoll-Dayton B, Spencer B (2015) Communication and relationship quality in later-life couples coping with dementia. The Gerontologist 55(Suppl2):666. https://doi.org/10.1093/geront/gnv346.11

Loseke DR, Kurz D (2005) Men's violence toward women is the serious social problem. In: Loseke DR, Gelles RJ, Cavanaugh MM (eds). Current controversies on family violence. Sage, Thousand Oaks, CA, pp. 79-96

Lövestad S, Löve J, Vaez M, Krantz G (2017) Prevalence of intimate partner violence and its association with symptoms of depression; a cross-sectional study based on a female population sample in Sweden. BMC Public Health 17 (1):335. https://doi.org/10.1177/0886260509336957

Ministerul Sănătăţii (2018) Ordinul nr. 742/2018 pentru aprobarea Regulamentului de organizare si functionare al Institutului National de Gerontologie si Geriatrie "Ana Aslan", București, Publicat în Monitorul Oficial, Partea I nr. 560 din 04 iulie 2018. Formă aplicabilă la 20 martie 2019, [Ministry of Health-Order no. $742 / 2018$ for the approval of the Regulation on the organization and functioning of the National Institute of Gerontology and Geriatrics "Ana Aslan", Bucharest, Published in the Official Gazette, Part I no. 560 of July 4, 2018. Form applicable on $20 \mathrm{Mar}, 2019]$ Retrieved $1 \mathrm{Mar}$, 2019, from https://ana-aslan.ro/wp-content/ uploads/2019/03/REGULAMENT-DE-ORGANIZARE-SI-FUNCTIONARELA-NIVEL-DE-INSTITUT-APROBAT-PRIN-ORDIN-MS-NR-742-2018-2.pdf 
Monitorul Național Nr. 389 (2016) Noul Cod Penal actualizat prin: OUG nr. 18/ 2016 pentru modificarea și completarea Legii nr. 286/2009 privind Codul penal, Legii nr. 135/2010 privind Codul de procedură penală. Monitorul Oficial 389(2016). [New Criminal Code updated by: Government Emergency Ordinance no. 18/2016 for amending and completing the Law no. 286/2009 on the Criminal Code, Law no. 135/2010 on the Criminal Procedure Code, as well as for completing the art. 31 par. (1) of the Law no. 304/2004 on judicial organization, Official Gazette no. 389/2016]. Retrieved 25 Feb, 2019, from https://legeaz.net/noul-cod-penal/art-219

National Center for Injury Prevention and Control, Division of Violence Prevention, USA (2019) Preventing Intimate Partner Violence. Retrieved from 19 Mar, 2020, https://www.cdc.gov/violenceprevention/intimatepartnerviolence/ fastfact.html

Newfoundland and Labrador-Canada (2018) Defining violence and abuse. Retrieved 01 May, 2019, from Violence Prevention Initiative: https://www. gov.nl.ca/VPI/types/index.html

Office for National Statistics, UK (2015) Intimate personal violence and partner abuse. Retrieved $25 \mathrm{Feb}, 2019$, from https://www.ons.gov.uk/ peoplepopulationandcommunity/crimeandjustice/compendium/ focusonviolentcrimeandsexualoffences/yearendingmarch2015/ chapter4intimatepersonalviolenceandpartnerabuse\#prevalence-ofintimate-violence-extent

Olson DH (1995) Family satisfaction scale. Prepare/Enrich, Roseville, Minnesota

Olson DH (2010) FACES IV manual. Life Innovations, Minneapolis, MN

Olson DH, Barnes HL (1995) Family communication scale. Prepare/Enrich, Roseville, Minnesota

Parkinson D (2017) Intimate partner sexual violence perpetrators and entitlement. In: McOrmond-Plummer L, Levy-Peck JY \& Easteal P (eds). Perpetrators of intimate partner sexual violence: a multidisciplinary approach to prevention, recognition, and intervention. Taylor \& Francis, Oxford, UK. pp. 44-45. Retrieved 25 Feb, 2019, from https://doi.org/10.4324/9781315693422

Paul G, Smith SM, Long J (2006) Experience of intimate partner violence among women and men attending general practices in Dublin, Ireland: A crosssectional survey. Eur J Gen Pract 12(2):66-69. https://doi.org/10.1080/ 13814780600757344

Payne BK (2008) Training adult protective services workers about domestic violence: training needs and strategies. Violence Against Women 14:1199-1213. https://doi.org/10.1177/1077801208322702

Rețeaua pentru prevenirea și combaterea violenței împotriva femeilor [Network for Preventing and Combating Violence Against Women, Network VIF] (2018) Peste 1.000 de persoane au participat la marșul'Împreună pentru siguranța femeilor" [More than 1,000 people participated in the "Together for Women's Safety"] Retrieved February 2019, 2019, from: https:// violentaimpotrivafemeilor.ro/peste-1-000-de-persoane-au-participat-lamarsul-impreunap-entru-siguranta-femeilor-2018/

Rada C, Tarcea M (2010) Viața sexuală şi familia în mediulurban românesc. Studiul Rada-Tarcea [Sexual and family life of the Romanians.Study Rada-Tarcea]. Institutul European, Iaşi

Rada C (2014) Violence against women by male partners and against children within the family: prevalence, associated factors, and intergenerational transmission in Romania:a cross-sectional study. BMC Public Health 14:129. https://doi.org/10.1186/1471-2458-14-129

Rada C (2017) Latent class analysis approach for the Family Adaptability and Cohesion Evaluation Scale IV among young people from Romania: the first step for validation. J Fam Issues 39(6):1598-1615. https://doi.org/10.1177/ 0192513x17714508. Retrieved $25 \mathrm{Mar}, 2020$

Rada C (2018a) Spending leisure time when approaching retirement and during retirement. Revista de Psihologie 64(4):265-280. http://revistadepsihologie. ipsihologie.ro/images/revista_de_psihologie/Rev.-psihologie-4-2018.pdf. Retrieved 5 Jan, 2019

Rada C (2018b) Ageing and intergenerational care. Anthropol Res Stud 8:134-143. https://doi.org/10.26758/8.1.13.

Rada C (2019) Psychometric quality of family adaptability and cohesion evaluation scale IV by latent class analysis; quantitative study on the elderly in Romania. Anthropol Res Stud 9:100-115. https://doi.org/10.26758/9.1.10.2019. Retrieved $20 \mathrm{Mar}, 2020$

Razera J, Gaspodin IB, Falcke D (2017) Intimate partner violence and gender a/ symmetry: an integrative literature review. Psico-USF 22(3):401-412. Retrieved 1 Feb, 2019, from www.scielo.br https://doi.org/10.1590/1413-82712017220302

Rees K, Zweigenthal V, Joyner K (2014) Health sector responses to intimate partner violence: a literature review. Afr J Prim Health Care Family Med 6 (1):1-8. https://doi.org/10.4102/phcfm.v6i1.712

Revnic C, Pena C, Prada S, Revnic F, Prada G (2016a) The effect of gerovital H3 upon cardiac contractility in patients with mitral valve insufficiency Rom J Geront Geriatr 5(1):3-8 http://www.rigg.ro/pdf/the-effect-of-gerovital-h3-upon-cardiaccontractility-in-patients-with-mitral-valve-insufficiency-1505296025.pdf

Revnic CR, Pena C, Prada S, Revnic F, Prada G (2016b) 1H NMR studies of erythrocyte membrane permeability in rats with experimental artherosclerosis. The impact of procaine or Aslavital treatment Rom J Geront Geriatr 5(2):3-7. http:// www.rigg.ro/pdf/lh-nmr-studies-of-erythrocyte-membrane-permeability-inrats-with-experimental-artherosclerosis-the-impact-of-procaine-or-aslavitaltreatment-1489396330.pdf

Reske-Nielsen C, Medzon R (2016) Geriatric trauma. Emerg Med Clin North Am 3: 483-500. Retrieved 25 Feb, 2019, from https://doi.org/10.1016/j.emc.2016.04.004

Roberto KA, McCann BR, Brossoie N (2013) Intimate partner violence in late life: an analysis of national news reports. Violence Against Women 25(3):230-241. https://doi.org/10.1177/1077801213517564. Retrieved 17 Feb, 2019

Rujoiu V, Rujoiu O (2014) The medical approach on intimate partner sexual abuse: Romanian physicians' perspective. A qualitative analysis. Revista de Asistență Socială [Social Work Review](XIII.1), 101-119. Retrieved 26 Feb, 2019, from https://www.researchgate.net/publication/287997394_The_Medical_ Approach_on_Intimate_Partner_Sexual_Abuse_Romanian_Physicians'_Perspective_A_Qualitative_Analysis

Sandu ML, Tănase T, Postaru (Voinea) D, Nadoleanu G (2014) Domestic violence: a current problem of Romanian society. Acta Univ Danubius 8(1):119-132. http://journals.univ-danubius.ro/index.php/communicatio/article/view/2238 Retrieved 8 Feb, 2018

Stets J, Straus MA (1990) Gender differences in reporting marital violence and its medical and psychological consequences. In: Straus MA, Gelles RJ (eds) Physical violence in American families: risk factors and adaptations in American families. Transaction Books, New Brunswick, NJ, pp. 151-166

Stöckl H, Devries K, Rotstein A, Abrahams N, Campbell J, Watts C, Garcia Moreno C (2013) The global prevalence of intimate partner homicide: a systematic review. The Lancet 382(9895):859-865. https://doi.org/10.1016/S0140-6736 (13)61030-2. Retrieved 28 Feb, 2019

Swan S, Gambone L, Caldwell J, Sullivan T, Snow D (2008) A review of research on women's use of violence with male intimate partners. Violence Vict 23 (3):301-314. https://doi.org/10.1891/0886-6708.23.3.301

Teaster PB, Otto JM, Dugar TD, Mendiondo MS, Abner EL, Cecil KA (2006) The 2004 Survey of State Adult Protective Services: Abuse of adults 60 years of age and older. Retrieved from The National Adult Protective Services Association: http://www.napsa-now.org/wp-content/uploads/2012/09/2-14-06-FINAL-60 + REPORT.pdf

UN Women (2008b) Domestic violence intimate partner violence, Shelters. Retrieved 10 Feb, 2019, from Global Database on Violence against Women: http://evaw-global-database.unwomen.org/en/countries/europe/romania/ 2008/shelters

UN Women (2008a) Trainings and seminars for preventing domestic violence in rural areas. Retrieved $8 \mathrm{Feb}, 2019$, from global knowledge platform to end violence against women: http://evaw-global-database.unwomen.org/en/ countries/europe/romania

Vaeth PA, Ramisetty-Mikler S, Caetano R (2009) Depression among couples in the United States in the context of intimate partner violence. J Interpers Violence 25(5):771-790. https://doi.org/10.1177/0886260509336957

Vrăbiescu I (2018) Creating solidarity: Intimate partner violence (IPV) and politics of emotions in a multi-ethnic neighbourhood in Romania. Eur J Women's Stud. Retrieved 1 Feb, 2019, from https://doi.org/10.1177/1350506818785202

Walker R, Isherwood L, Burton C, Kitwe-Magambo K, Luszcz M (2013) Marital satisfaction among older couples: the role of satisfaction with social networks and psychological well-being. Int J Aging Hum Dev 76(2):123-139. https:// doi.org/10.2190/AG.76.2.b. Retrieved 1 Mar, 2019

Watson D, Parsons S (2005). Domestic abuse of women and men in Ireland: report on the national study of domestic abuse. Retrieved 10 Jan, 2019, from National Crime Council: http://www.cosc.ie/en/COSC/Abuse\%20Report\% 20NCC.pdf/Files/Abuse\%20Report\%20NCC.pdf

World Health Organization (2017) Abuse of older people on the rise-1 in 6 affected. Retrieved 14 Feb, 2019, from World Health Organization: https:// www.who.int/news-room/detail/14-06-2017-abuse-of-older-people-on-therise-1-in-6-affected

Yon Y, Mikton CR, Gassoumis ZD, Wilber KH (2017) Elder abuse prevalence in community settings: a systematic review and meta-analysis. Lancet Global Health 59(2):147-156. Retrieved 14 Feb, 2019 https://www.thelancet.com/ action/showPdf?pii=S2214-109X\%2817\%2930006-2

Zhang H, Fan S, Yip P (2016) Marital satisfaction trends in Hong Kong between 2002 and 2012. J Sex Marital Ther 42(5):393-402. https://doi.org/10.1080/ 0092623X.2015.1053021. Retrieved 28 Feb, 2020

\section{Acknowledgements}

The quantitative data of this study were based on the project "Quantitative and qualitative study on successful aging: A psycho-socio-medical approach on third age" made by "Francisc I. Rainer" Anthropology Institute of the Romanian Academy (No. 691/ 12.08.2015) and "Ana Aslan" National Institute of Gerontology and Geriatrics (No. 10413/01.09.2015) from Bucharest. The topic was approved by the Scientific Council of the "Francisc I. Rainer" Anthropology Institute of the Romanian Academy (No. 1021/ 04.11.2015). Project managers: Rada C. and Drăghici R. Participants: Ispas A.T., Baciu A. 
B., Prada G.I., Pena C., Vârtan I., Stan P., and Lazăr C. To carry out this project, the work was voluntary, with no one receiving payment.

\section{Competing interests}

The author declares no competing interests.

\section{Additional information}

Correspondence and requests for materials should be addressed to C.R.

Reprints and permission information is available at http://www.nature.com/reprints

Publisher's note Springer Nature remains neutral with regard to jurisdictional claims in published maps and institutional affiliations. (c) (i) Open Access This article is licensed under a Creative Commons Attribution 4.0 International License, which permits use, sharing, adaptation, distribution and reproduction in any medium or format, as long as you give appropriate credit to the original author(s) and the source, provide a link to the Creative Commons license, and indicate if changes were made. The images or other third party material in this article are included in the article's Creative Commons license, unless indicated otherwise in a credit line to the material. If material is not included in the article's Creative Commons license and your intended use is not permitted by statutory regulation or exceeds the permitted use, you will need to obtain permission directly from the copyright holder. To view a copy of this license, visit http://creativecommons.org/ licenses/by/4.0/.

(C) The Author(s) 2020 